\title{
Failure Analysis of 6.8 Evaporator Thermowell (U)
}

\author{
J. I. Mickalonis, D. Z. Nelson, and C. N. Foreman \\ Savannah River Technology Center \\ Strategic Materials Technology Department \\ Materials Technology Section
}

June, 2004

\section{Westinghouse Savannah River Company Savannah River Site Aiken, SC 29808}

This document was prepared in connection with work done under Contract No. DE-AC09-96SR18500 with the U. S. Department of Energy 
This document was prepared in conjunction with work accomplished under Contract No. DE-AC09-96SR18500 with the U. S. Department of Energy.

\section{DISCLAIMER}

This report was prepared as an account of work sponsored by an agency of the United States Government. Neither the United States Government nor any agency thereof, nor any of their employees, makes any warranty, express or implied, or assumes any legal liability or responsibility for the accuracy, completeness, or usefulness of any information, apparatus, product or process disclosed, or represents that its use would not infringe privately owned rights. Reference herein to any specific commercial product, process or service by trade name, trademark, manufacturer, or otherwise does not necessarily constitute or imply its endorsement, recommendation, or favoring by the United States Government or any agency thereof. The views and opinions of authors expressed herein do not necessarily state or reflect those of the United States Government or any agency thereof.

This report has been reproduced directly from the best available copy.

Available for sale to the public, in paper, from: U.S. Department of Commerce, National Technical Information Service, 5285 Port Royal Road, Springfield, VA 22161, phone: (800) 553-6847, fax: (703) 605-6900

email: orders@ntis.fedworld.gov

online ordering: http://www.ntis.gov/help/index.asp

Available electronically at http://www.osti.gov/bridge

Available for a processing fee to U.S. Department of Energy and its contractors, in paper, from: U.S. Department of Energy, Office of Scientific and Technical Information, P.O. Box 62, Oak Ridge, TN 37831-0062,

phone: (865)576-8401,

fax: (865)576-5728

email: $\underline{\text { reports@ adonis.osti.gov }}$ 
This page was intentionally left blank 


\section{Table of Contents}

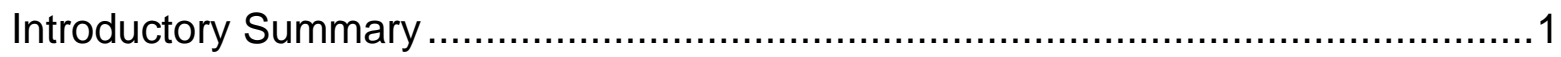

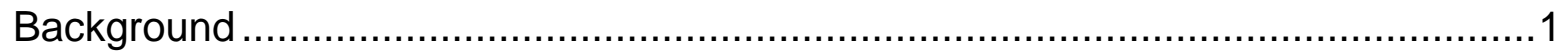

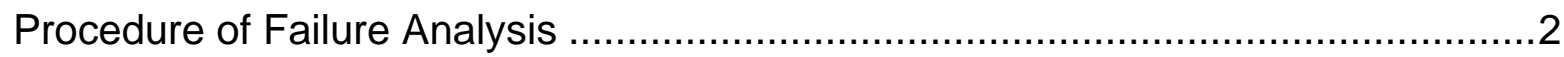

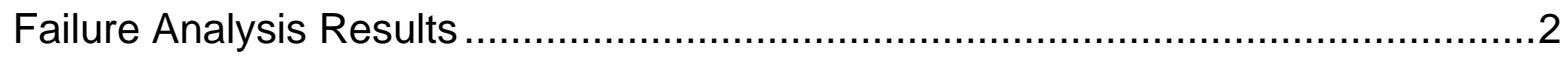

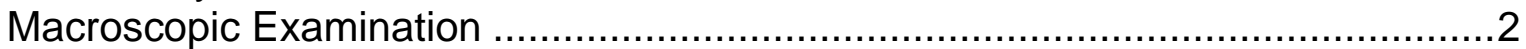

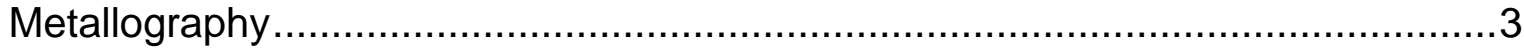

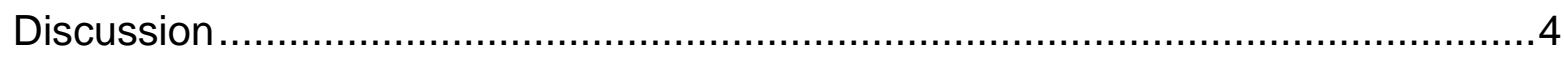

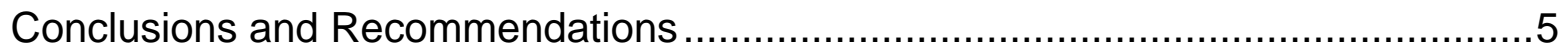

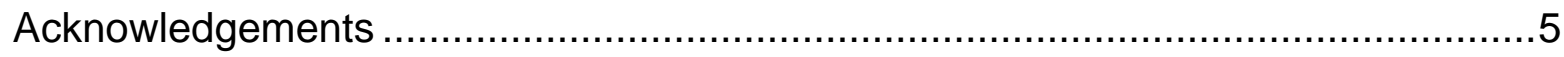

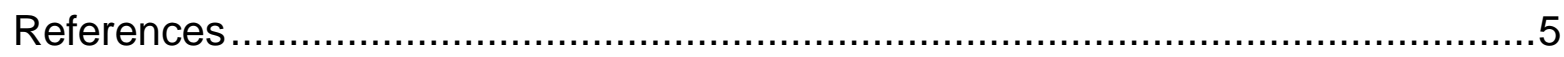

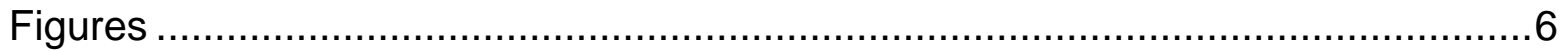


WSRC-TR-2004-00075

\section{Introductory Summary}

SRTC/Materials Technology Section was requested to determine the cause of failure for a resistance temperature device (RTD) and thermowell assembly that was used in the 6.8 Low Activity Waste (LAW) evaporator. A methodical and well planned approach was used for the failure analysis task with special precautions because of the high radiation and contamination levels. Two sections of the failed assembly were selected for thorough analysis, the bottom of the inner tube with the end-cap and a piece of inner tube at the vapor/waste interface. The failure analysis consisted of macroscopic examination and metallographic analysis. Intergranular attack (IGA) was found to be the primary corrosion mechanism that led to eventual failure. IGA of the end cap occurred because of a presumed preferential microstructure and accelerated the corrosion rate over that of inner-tube side wall. Once the end cap was breached, the waste quickly attacked the RTD components, leading to the low resistance to ground readings that indicated the initial RTD malfunction. A metallographic analysis of an unexposed end cap is recommended to confirm the suspect microstructure.

\section{Background}

Low resistance-to-ground readings were found for the resistance temperature device in the $\mathrm{H}$ canyon 6.8 LAW evaporator during August 2003. This event occurred approximately 14 months after this new RTD was put into the evaporator. The previous RTD in this evaporator had also failed and was caused by penetration of the thermowell which houses the RTD. After the first failure, an 18-month inspection/replacement interval was imposed since the RTD is safety class equipment [1].

The thermowell from the current failure was presumed to have also been penetrated. Initial testing and observations, however, did not support this conclusion. The drawing of a thermowell is shown in Figure 1. No leak was found when the inner tube was pressure tested to $50 \mathrm{psi}$. After this test, the RTD could not be removed from the thermowell, which was atypical. During the replacement of the RTD and thermowell, significant moisture was noted on the RTD wiring between the Upper and Lower Hanford connectors. The connector pins in the upper Hanford connector were covered with a black film/coating indicating oxidation of the pins.

Field observations noted that there was no visible wall thinning observed on the thermowell or external support tube material. The areas of the external support that may have had exposed end grain did not appear to have been corroded. The lower section (expected liquid exposure) of the thermowell had a white to light grey grainy coating while the upper section (expected vapor exposure) had a black granular coating.

During the 14-month exposure time, the evaporator was not operated when the digital control system (DCS) was tied in. Data, then taken from the DCS, showed that the thermowell and RTD operated for 3,440 hours at temperature over $100{ }^{\circ} \mathrm{C}$. The evaporator normally operates continuously except for cool down for outages, clean out of concentrated waste, and lack of feed material. 
The thermowell components were fabricated from 304L stainless steel. The materials of construction for the RTD outer body included aluminum, copper and stainless steel.

The failed RTD/thermowell assembly was cut into short sections and selected sections were packaged in a large polyethylene bottle then shipped to SRTC for failure analysis.

\section{Procedure For Failure Analysis}

Prior to receiving the thermowell and performing the failure analysis in the laboratory, precautionary steps were taken because of the high radiation and contamination levels. The radiation survey performed by the $\mathrm{H}$-area RCO indicated that the beta/gamma extremity dose rate was approximately 20-25 rem per hour and the contamination levels were 50 rad beta/ gamma and 200,000 alpha dpm. The contamination levels, though a concern, did not exceed Contamination Area hood guidelines set forth in the Radiation Work Practices procedure [3]. A job hazards analysis and a special radiation work permit with an ALARA review were completed. After completion of these tasks, the Facility Radiation Activity Team (FRAT) reviewed the planned approach and gave approval prior to the start of work. The scope of work and prepared documentation originally planned for the thermowell failure analysis was changed due to the measured dose rate found during unpackaging of the received sections.

Eleven pieces were received for analysis; 8 inner tube sections of approximately 8 - 10 inches long, 4 outer tube sections that were approximately 8-10 inches long, and one short section 3 inches long as shown in Figure 2. Three sections were selected for closer examination. The sections were the bottom and end cap of the inner tube, the vapor/waste interface area of the inner tube, and a section of the outer tube. The end-cap design for this thermowell is shown by the arrow in Figure 1. The bases for these selections were formed from the previous thermowell failure analysis results [1] and the known corrosion processes of 304L stainless steel [4]. The other sections were removed from the hood to reduce the radiation dose rate during the failure analysis.

The RTD/thermowell failure analysis involved numerous steps which initiated with macroscopic examination and photography as noted above. Surface scrapings were taken and evaluated by $\mathrm{x}$ ray diffraction. The tube sections were decontaminated prior to further work. Pertinent areas of the tubes were sectioned for metallographic analysis. This analysis involved mounting pieces in holders, grinding, polishing, and etching the samples. The results are discussed below following these outlined steps

\section{Failure Analysis Results}

The failure analysis consisted of macroscopic examination and metallographic analysis of the microscopic features of the failure location.

\section{Macroscopic Examination}

The tube sections, as shown in Figure 2, had either a dark or light appearance. The light appearance was associated with a light gray deposit that occurred on sections exposed to the 
waste. The darker sections were presumed to have been exposed to the vapor only. The inner tube end-cap and the vapor/waste transition sections were covered with the deposit that appeared to have precipitated from the waste. Scrapings from each of the inner tube sections were taken for x-ray analysis. The black layer on the outer tube appeared more tenacious and was probably an oxide. Though high extremity radiation dose rates were still present, collection of the scrapings had to be accomplished before decontamination was attempted. Scrapings of the outer tube were not taken since the failure point was suspected to be in the waste-exposed sections. The x-ray analysis showed that the deposits were calcium sulfate, both the anhydrous and hydrated forms.

Decontamination was then performed to remove the light gray coating and to reduce the radiation dose rates before further analysis was attempted. The decontamination process included immersion of both pieces in a mild-alkaline cleaning solution. The tube end-cap section was not submerged below the upper opening so as not to wet the interior. Any liquid allowed into the inside of the end cap would have caused the destruction of evidence needed to determine the direction of failure.

After the two inner tube sections were soaked for twenty-four hours, a light brushing with a nylon bristle brush was performed which easily removed most of the white deposit. The pieces were placed into new cleaning solution and soaked for an additional twenty four hours. The dose rates were successfully reduced which reduced the hazards associated with the remaining failure analysis steps.

A closer visual examination was conducted of the end-cap and vapor/waste transition sections. Discoloration was noted in two specific areas on the end cap. Corrosion pits were found in both discolored areas as shown in Figure 3. Overall corrosion was found on the entire length of the end-cap section with the greatest distribution of pits on the end. The general degradation was manifested as a roughened surface. Recall that this section was composed of a short piece of tube, the tube/end-cap weld, and the end cap. The end cap had not been buttered or coated with weld metal. The tube/end-cap weld had less apparent corrosion than had generally occurred over the remainder of the section. Closer examination of the vapor/waste transition section showed heavy discoloration with general intergranular attack along the entire outer surface. This general attack seemed to indicate the corrosion was similar for both the vapor space and liquid region.

Metallography

The end cap and the tube/end-cap weld were sectioned into separate pieces prior to mounting as shown in Figure 4. Note the reddish corrosion products on the interior of the end cap, which give a rough appearance. The outer tube was not sectioned for metallographic analysis to reduce personnel exposure. Also, more severe corrosion occurred on the inner tube as shown by a previous thermowell failure analysis [1]. The weld and end-cap pieces were then split longitudinally to expose the inner and outer surfaces in a metallographic mount. By sectioning and mounting in this manner, the specific leak path, direction of pit growth and general condition of the inner and outer walls could be determined. Following grinding, the mounts were polished per standard 304L techniques and etched using 10\% oxalic acid at 6.0 V dc current. 
Metallographic analysis of the end cap revealed that pitting and intergranular attack (IGA) had lead to penetration of the end-cap wall from the outside. Although only one corrosion pit was examined extensively on the particular polished plane, additional corrosion pits had been noted initially (Figure 3) and may have also penetrated the end-cap wall. The largest pit breached the wall in 3 main places; one location is shown in Figure 5. IGA was present over the entire outer surface of the end cap. Note the highly worked microstructure of the bottom inner surface on the end cap near the top of Figure 5. This microstructure had a circuitous grain boundary. The corrosion products were analyzed from the inner surface of the end cap and found to be ferrous and aluminum oxides and hydroxides.

The RTD probe was removed and examined during the analysis of the end cap. Evidence of corrosion was present on the aluminum sleeve that covers the inner probe. The corrosion product was uniform over the entire surface of the sleeve which would indicate the entire probe was susceptible to the corrosive environment introduced by the through wall pit in the end cap. The end of the probe that comes in direct contact with the end cap was no longer smooth and flat but had degraded to the point where some probe material had completely dissolved into solution and was no longer present.

The tube/end-cap weld was examined and found to be less susceptible to corrosion than the end cap as shown in Figure 6. A previous examination of a failed thermowell indicated that weld metal was less susceptible than the tube material. In fact, the only material left from the bottom section of the previously examined thermowell was just a strip of the longitudinal weld. During the current failure analysis, a marked difference in the grain size and microstructure was noted between the tube and end cap indicating a difference in manufacturing of the two components. Also, noted but not deemed to be a factor in the failure was the lack of fusion of the end cap weld on the interior of the tube. Lack of fusion could cause problems and should be addressed.

The vapor/waste transition of the tube was examined for differences in the corrosion with the vapor and liquid exposure. A difference in corrosion was not found and the entire transition region was degraded from IGA, similar to the tube/end-cap weld region. However, the IGA was not as substantial in the transition region as on the end of the tube as shown in Figure 7. Compare this figure with Figure 6.

\section{Discussion}

The failure analysis results showed that IGA, pitting, and general corrosion were the active corrosion processes that lead to the penetration of the thermowell and failure of the RTD. IGA was noted on both the tube outer wall and the end-cap. Significant pitting was not detected on the tube wall. The primary corrosion mechanism was then IGA. Microstructural differences between the end cap and the tube probably lead to different rates of degradation. The end cap is suspected to have had exposed end grains, which are not apparent in the tube microstructure as shown in Figure 6. For the end cap, IGA may have lead to eventual grain drop out, thereby increasing the degradation rate and leading to pit-like formations. The IGA continued to progress until the end cap was penetrated, providing a pathway for the waste to inside the tube. 
The corrosion rate of the thermowell end cap was large. The inner tube is made from $1 / 2$ " schedule 40 pipe, which has a nominal thickness of 0.109 ”. The RTD/thermowell assembly failed in 14 months (approximately 1.2 years). Although at temperatures over $100 \mathrm{C}$, the assembly had 3,440 hours (approximately 0.4 year). The corrosion or degradation rate would fall between 95 to 280 mils per year. The conditions, including the exposure and material, are extremely aggressive.

Once the waste entered the tube, aggressive general corrosion of the copper plug occurred. Copper corrosion in nitric acid is greater than 50 mils per year [5]. The copper completely dissolved which disrupted the primary path for thermal conduction to the RTD. The aluminum corrosion products on the tube interior indicated corrosion of the aluminum sleeve on the RTD. The aluminum would also be attacked by the acidic waste.

\section{Conclusions and Recommendations}

The failure of the 6.8 thermowell and RTD resulted from IGA of the end cap and general corrosion of the RTD components. The end cap microstructure probably accelerated the attack because of end grain effects. A metallographic examination of an unexposed end cap is recommended to confirm the expected microstructure. If confirmed, changes in the end cap may be necessary to extend the life of the thermowell.

\section{Acknowledgements}

The authors want to acknowledge the support of the following groups that made this failure analysis possible: H-Canyon Engineering, H-Canyon RCO, H-Canyon Operations, SRTC RCO, SRTC/ADS and Construction.

\section{References}

1. P. Vormelker and J. I. Mickalonis, "Analysis Of Thermowell Failure From 6.8 Batch Evaporator Tank In H Canyon (U),” WSRC-TR-2003-00259, June 30, 2003.

2. G. Antaki, "Integrity of H-Canyon Evaporators: 6.8E, 7.6E, 7.7E," T-TRT-H-00002, Revision 0, October, 2003.

3. Procedure 2.32, “Radiological Work Practices,” SRTC Procedures Manual L1, 11/17/2003.

4. A. J. Sedricks, Corrosion of Stainless Steel, $2^{\text {nd }}$ ed, John Wiley \& Sons, Inc, New York, 1996.

5. P. A. Schweitzer, Corrosion Resistance Tables, $3^{\text {rd }}$ edition, Marcel Dekker, Inc, New York, 1991. 


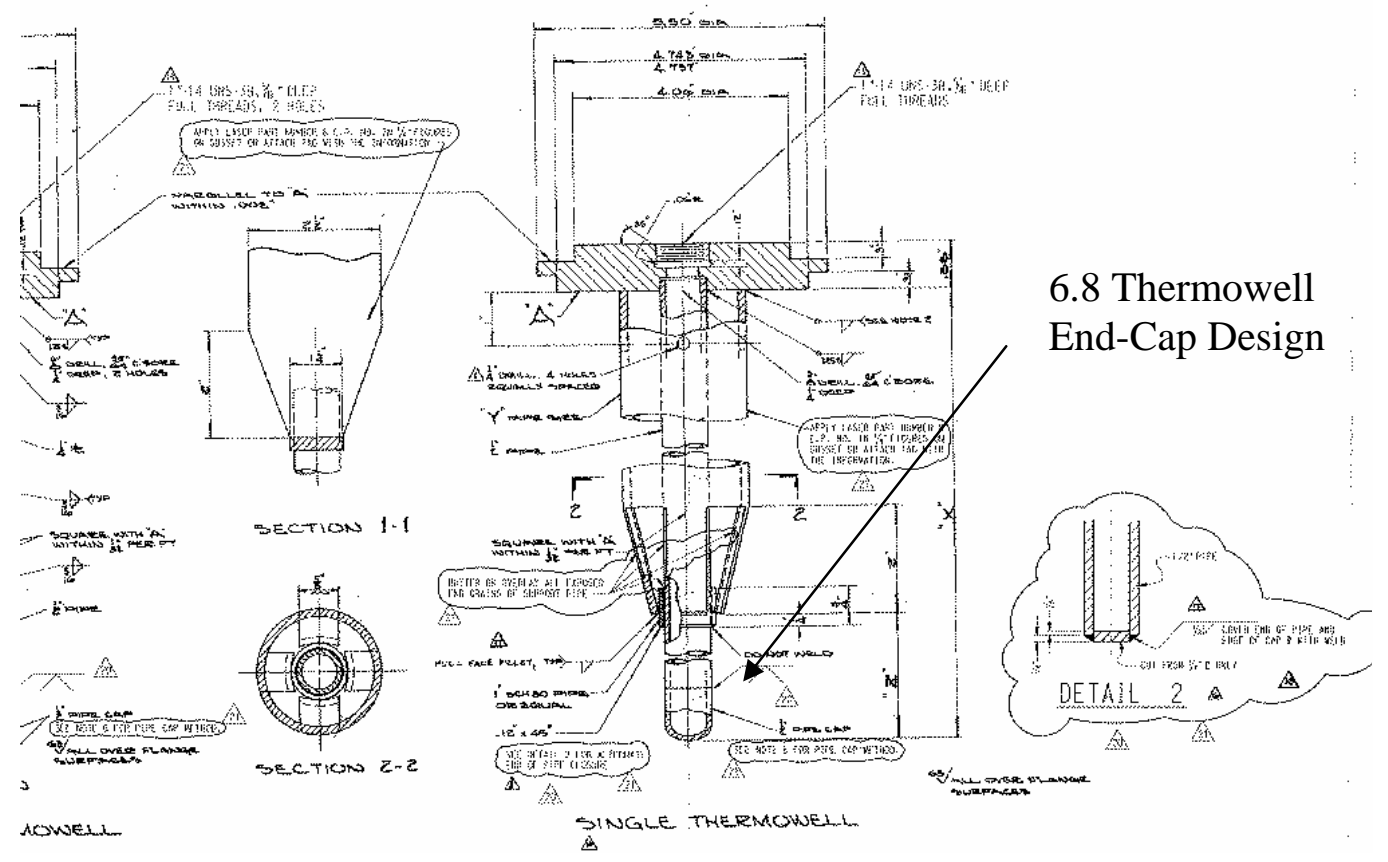

Figure 1. Drawing of Jumper Thermowell For LAW Evaporators (D138562).

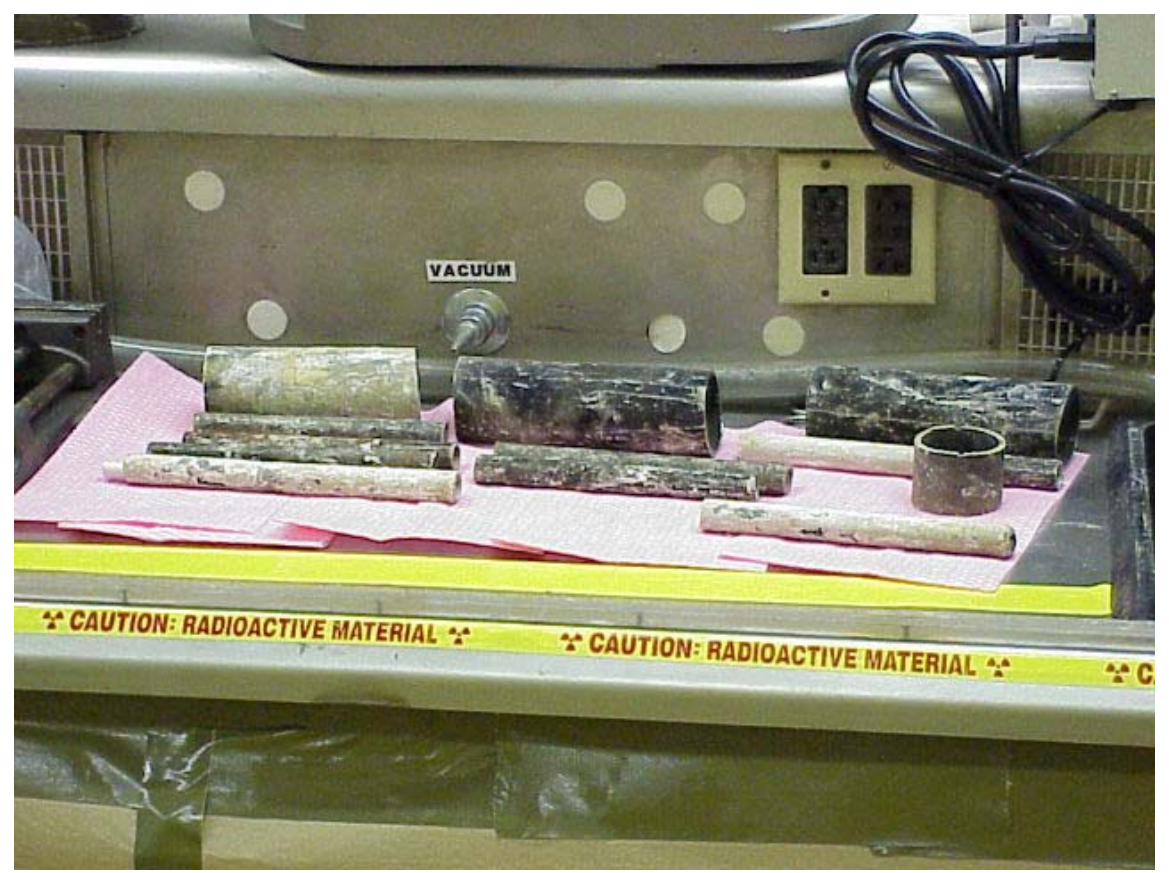

Figure 2. 6.8 Thermowell received in SRTC for analysis 


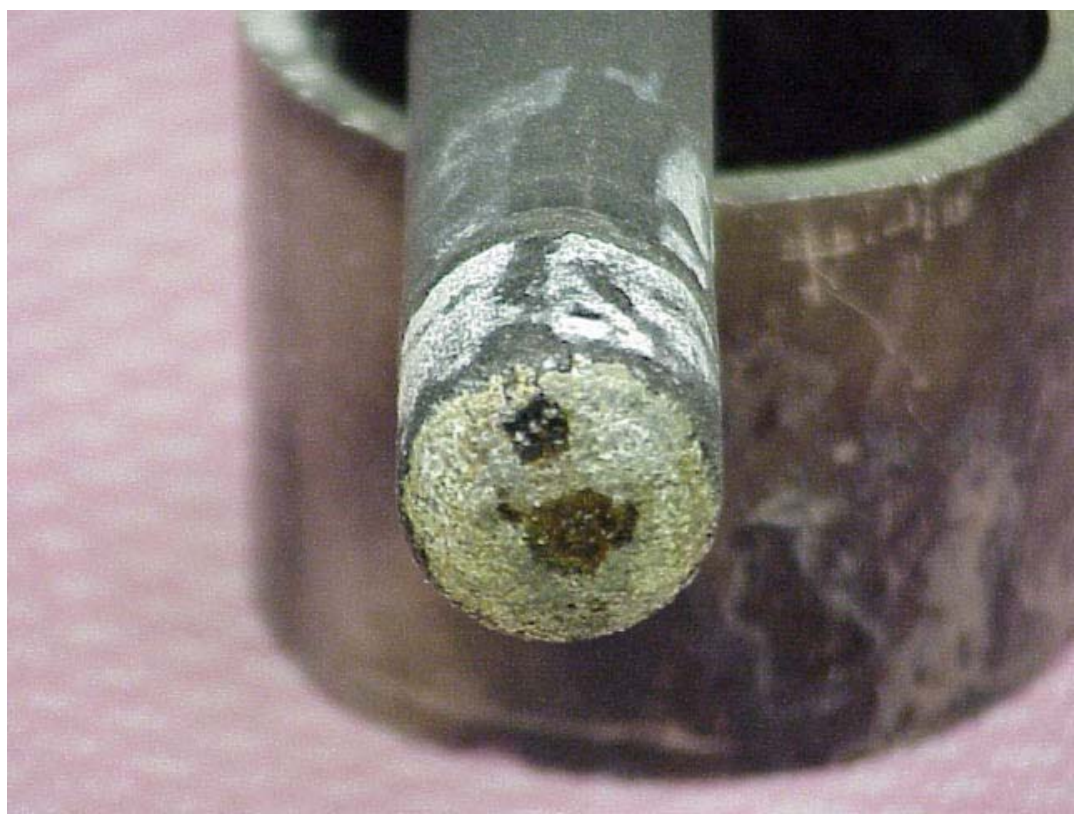

Figure 3. 6.8 Thermowell End cap showing oxide covered surface with corrosion pits

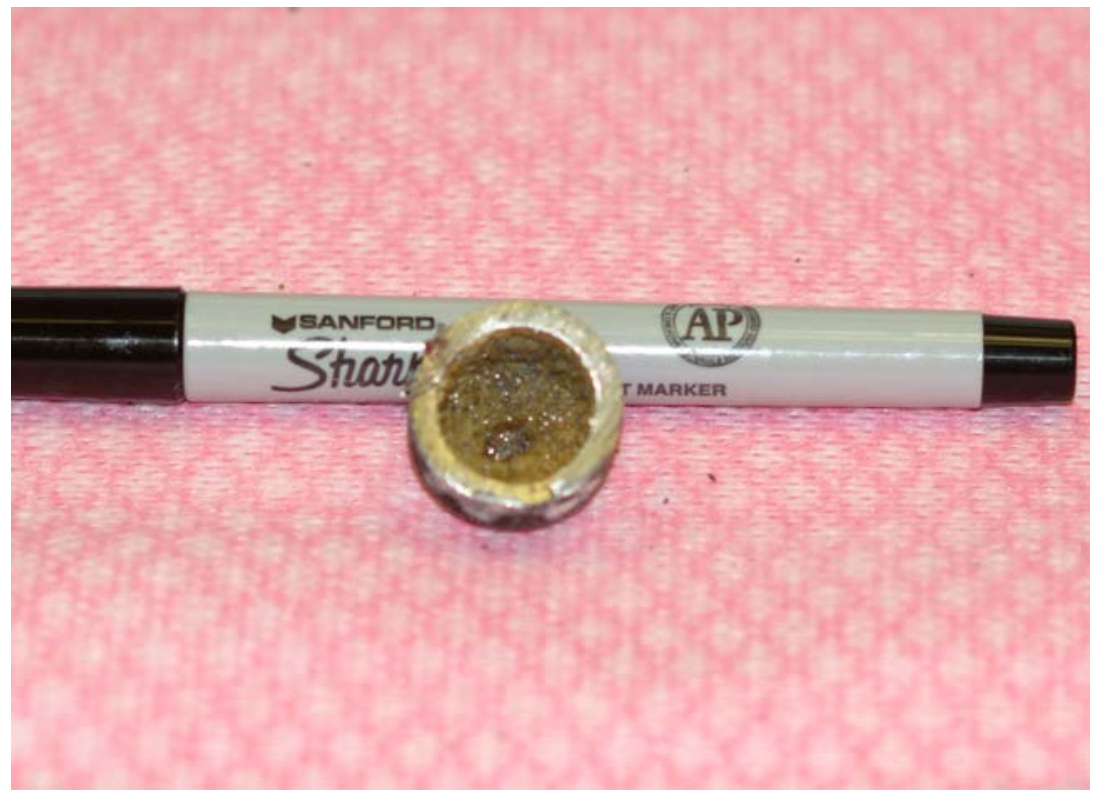

Figure 4. Sectioned end cap showing interior corrosion product 


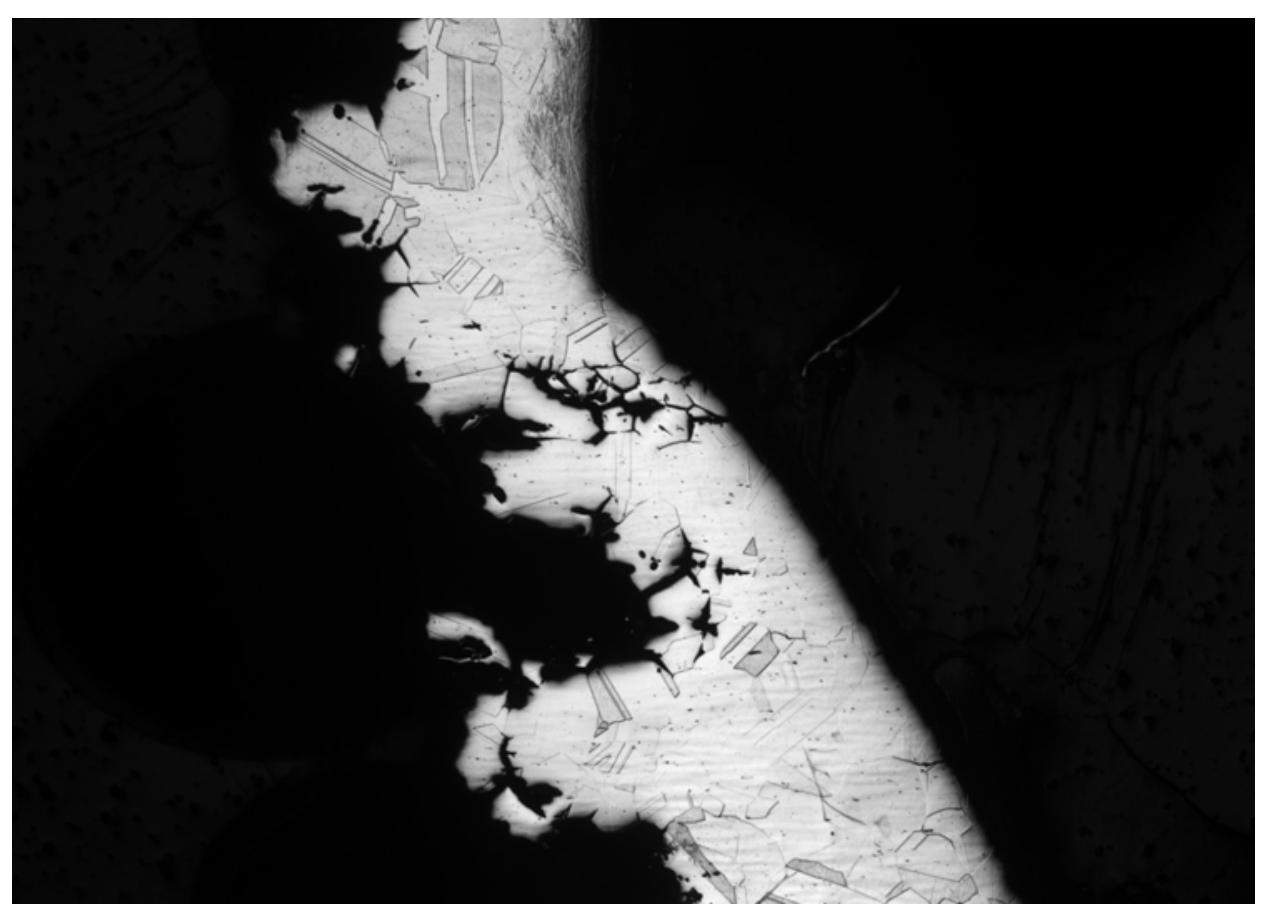

Figure 5. Through wall corrosion pits in bottom of the end cap

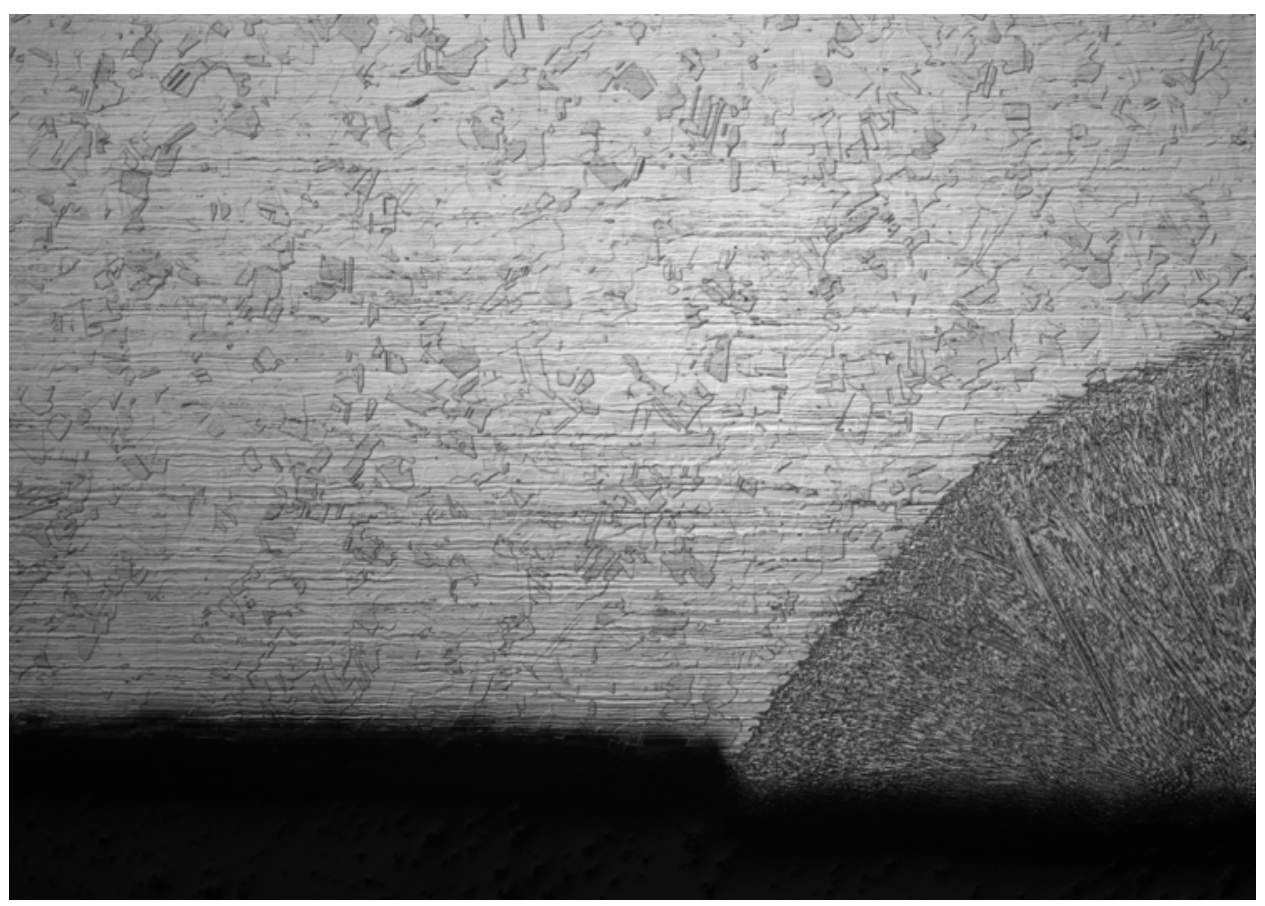

Figure 6. Weld between end-cap side wall and inner tube 
WSRC-TR-2004-00075

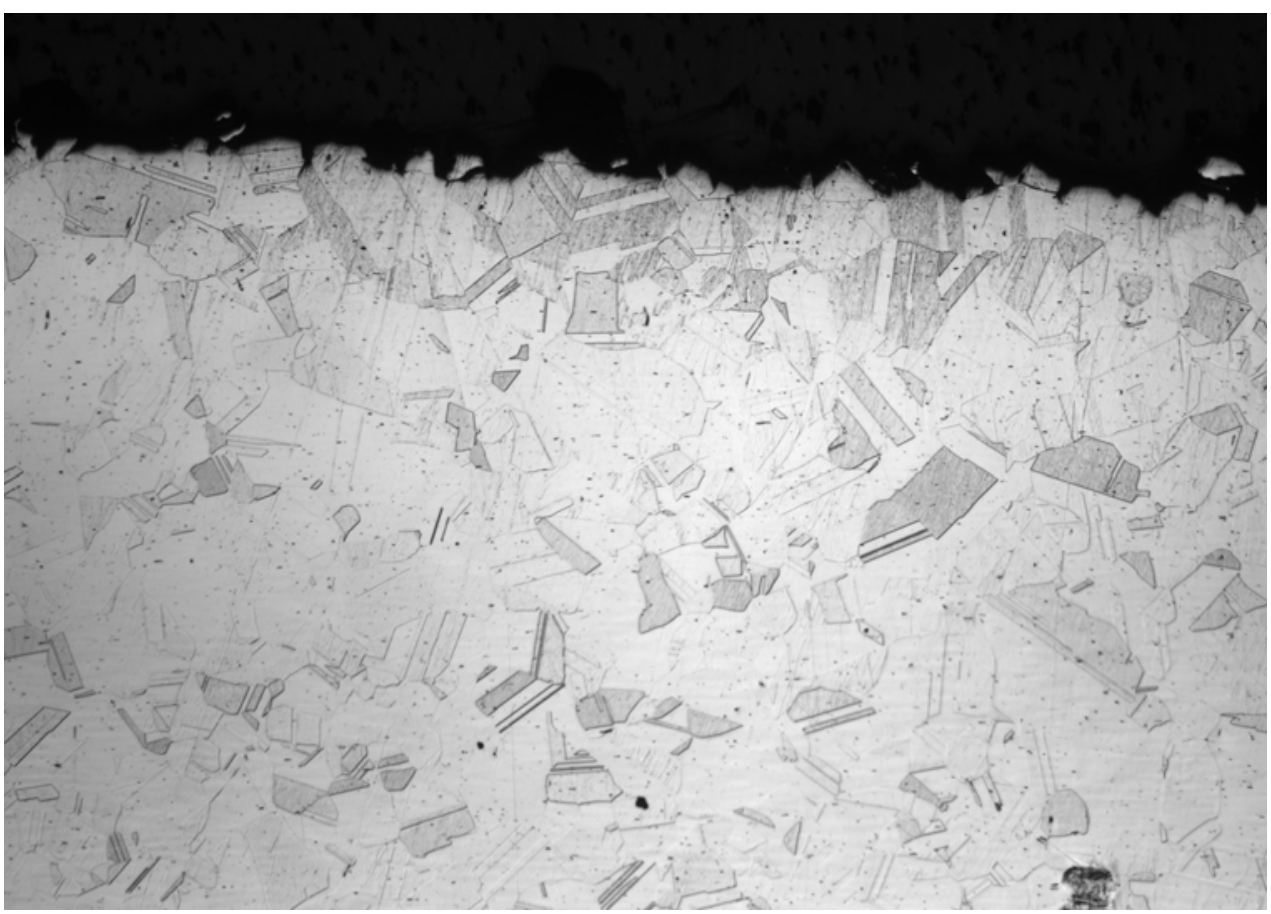

Figure 7. Intergranular attack of the inner-tube surface in the vapor/waste transition region. 